\title{
Interrogating the Fundamentals of Identity: Changez's Defining Act in the Reluctant Fundamentalist
}

\author{
Sumbal Maqsood \\ Assistant Professor in English \\ GC University \\ Lahore, Pakistan
}

\begin{abstract}
In this paper, I will be exploring the dramatic transformation in the character of Changez in Mohsin Hamid's dramatic monologue The Reluctant Fundamentalist. This transformation is like a Žižekian act which Changez executes in order to redefine his coordinates of reality. Žižek believes that an act is essential in order to reform individuals and the societies which they are a part thereof. It opens up a plethora of possibilities that the individual explores in order to arrive at a more coherent view of his perspective on life. Through an imperfect character like Changez, Hamid's work takes us on a journey of flashbacks, memories, and contemporary dilemmas that a modern day individual often faces. The social framework of communities gives coveted choices that would lead to ambitious paths of success, but pitfalls are always there in social myths of success in a society. What education systems and other institutes give us are ideal labels, boundaries and definitions according to which a society should function. But often, these fixed formulas are destined to fail, and an individual feels dislocated enough to question his reality, which was a vacuum all along. Using Žižek's ideas on artificial social constructs, this paper explores how pseudo-concepts of security, well-being and progressive identities of nations are actually traps of capitalism that reduce an individual to no more than an appendage in a society's machinery. When individuals realize the vicious circle of revolutions and counter-revolutions they are ensnared by, they are forced to question the fundamentals and values they believe in, and Changez is one such character.
\end{abstract}

Keywords: manipulation; fundamentalism; identity; reality.

Today, when we talk of common culture and everyday experiences, the name of Slavoj Žižek figures forth as a prominent one. Žižek eloquently explores through various treatises problems of psychology, ontology, globalization and with globalization, the increasingly precarious matter of identity. Žižek probes into modern power dynamics and points out how we are culprits in promulgating what we know are essentially wrong, yet we keep on doing it. Žižek advocates that individuals must 'act' in order to bring about a change in an essentially flawed social system. In the light of the propositions of Žižek, I will be looking at Mohsin Hamid's work The Reluctant Fundamentalism, which is an important contemporary work for the exploration of the subject of identity formation in the present world.

The Guardian considers Mohsin Hamid's The Reluctant Fundamentalist as one of those books that define the decade (2000-2010), particularly when we look at poignant events like the Twin Tower attacks. "The Twin Towers have gone up in flames again and again in a plethora of textual and visual narratives like novels, short stories, films, documentaries and prose analyses" (Awan 522). The Twin Towers collapse had to take place in order to redefine and rebuild identities, whether of power or religion. As can be observed in this quote, "power always has to rely on an obscene stain of violence - that is to say, political space is never "pure," it always involves some kind of reliance on "pre-political" violence" (Butler 234). Different works by various authors have depicted the Great American Tragedy as authentically as possible, and many literary works explore it in an imaginative light meant to evoke audience response. One such dramatic work is The Reluctant Fundamentalist which manages to rouse the sentiments of readers to active thinking, bringing alive the principle of Cartesian Cogito. Different readers from various geographical origins would be stimulated differently, but this is what a good book usually does. It challenges prevalent myths by placing forward a world of possibility. Awan says, "in the wake of 9/11 attacks, due to the myth-making capabilities of the American corporate media, new 'fears of the other' or the immigrant have been systematically induced in the minds of the American public" (525). These fears are like hypnotizing yet misleading ideological lies. 
Ideological lies have the capacity of changing many of us into unthinking mushrooms with a blinkered eye view that sidelines important realities, such as the reality of people we consider as 'outsiders'. Those who are excluded from the mainstream of a society become the blind spots which actually represent the latent truth of that society as these blind spots are refused effective participation. Changez is one such 'other', who responds in his own unique way to the post 9/11 scenario and questions the backlash of the American government and media towards the Muslims in general when fraternity, equality and justice were the key credentials of the American manifesto. In fact, Changez effectively performs an 'act' that enables him to unclench the hold of the American dream's hypnotism. "An act is a kind of re-birth of the subject. It involves a total rejection of the existing Symbolic Order and therefore of the Symbolic mandate or role assumed by the subject" (Myers 59). In Wood's work on Žižek, we observe a similar reiteration, "The act as reinventing one's symbolic identity is homologous to the Christian notions of spiritual rebirth and salvation" (201). Changez rejects the artificially awakened and nurtured desire associated with capitalist American life. He abandons the 'empirical' in favour of the 'transcendental' search for meaning. So Changez suddenly feels claustrophobic in his mandatory role of serving an American firm where he was bound by contract and symbolically, yet destructively, he chooses to fly back to his homeland, but nevertheless, it is a decisive choice. Changez must sacrifice his American experience in order to be reborn as a Pakistani Muslim. He feels, he must also shake himself free of the societal system of America and its various Ideological State Apparatuses (a term coined by Althusser). For instance, the patriotic fervor of the surplus American flags and mementos crowding the streets of New York remind Changez of American love for dominance asserting itself (90). This patriotic fervor soon turns into a frenzied revenge as America declared a retaliatory war on terrorism, mostly targeting Muslim countries. While the naïve would appreciate America's heroic endeavor, insightful analysts like Žižek elaborate the double standards of America in this extract: Here, I would like to propose the hypothesis that the US-Iraq war was, in terms of its actual sociopolitical content, the first war between the USA and Europe. That is to say: what if, as some economists have already suggested, the true economic aim of the war was not primarily the control of oil reserves but the strengthening of the US dollar, the prevention of the dollar's defeat against the euro, the prevention of the collapse of a dollar which is less and less "covered" by "real" value (think of the immense US debt)? (Iraq 36).

Unfortunately, most democracies fail to register the individual nature of every person residing in a declaredly democratic state. As Myers states, "You cannot see the world if you are part of it any more than you can see your own retina just by looking with it" (12). Unfortunately, most of us are afflicted with a predisposition to view the world from a blinkered perspective. When America is viewed as a democracy, the concept of the American Dream is inextricably linked with it. The American Dream offers unlimited opportunities and excess enjoyment which would be merely a notion for most countries of the world. Žižek goes a step ahead in viewing this enjoyment as a kind of jouissance, "surplus enjoyment that manifests as a strange fascination accompanied by uneasiness or discomfort" (Wood 4). When we look at Hamid's work, we are looking at a curious subject of American democracy with a distinctly Mughal Muslim name, that is, the protagonist Changez. Changez appears to be a character that seems to be garnering the fruits of this intense enjoyment of the American experience, but who must face a confrontational moment of uneasiness and discomfort that inevitably comes with the sacrifice to be made for the acquisition of the American Dream. The American Dream is a kind of ideology that Americans in general would love to believe in, but it is also a kind of success-myth for some, or an "error in perception" (Myers 19) for others who happen to live in another part of the world. Furthermore, the dollar, the statue of Liberty, and the Twin towers are some of the fetishes (also Marxist commodities) upon which the American Symbolic Order establishes itself. "A fetish is an object that fills in the constitutive lack or void around which the symbolic order revolves" (Wood 49). Even the educational system in America is a kind of fetish. America is a perfect capitalist heaven for the best minds in the world to sell themselves to become valuables in the world marketplace. This is the fantasy that America wants to keep on selling. Wood, while talking about the treatises of Žižek, admits, "Even though we in the USA all know that our so-called "democracy" is dysfunctional, somewhere there is someone who still believes in our democracy" (53). When Changez is a part of Princeton, he is practically swept off his feet by the academic environment, "I have access to this beautiful campus, I thought, to professors who are Titans in their fields and fellow students who are philosopher-kings in the making" (3). However, the indoctrination of Americanness in his personality was never consummated. This prevents him from embracing the American Identity fully and keeps him at crossroads with the background he emerged from. 
His Consultancy Firm Underwood Samson forms a defining feature of the capitalist world: it assesses various companies for their potential values before classifying them as fit for the business world with uncanny precision (5). Changez becomes an important cogwheel in their machinery. Eventually, Changez's transition is extraordinary when he starts criticizing U.S. militarist foreign policy, organizes student protests as a university professor, and becomes suspicious of Americans (as the one he meets in Lahore and possibly suspects him of being a CIA agent). The transition reflects the questioning of Changez regarding the supposedly infallible accuracy of American standards of judgment and supremacy, and as Žižek would identify, Changez undergoes a moment, not of epiphany, but "incommensurability or parallax gap" (Wood 6) where reality becomes different from the prophecy of the American promise. It is the Real that inevitably brings a smile upon Changez's face in the wake of the 9/11 attacks, despite the fact that America has given him top-quality education and a superb career to match. It is this smile that unfolds the reality of what Changez's innermost workings of the mind harbor. It can also be taken as a point of consideration that the vision of Changez at the beginning of Hamid's work shares a commonality with the vision of Changez at the end, that is both of them are "anamorphically distorted" (Myers 100). Initially, Changez's vision is distorted by prior knowledge of American greatness and later, by acquired knowledge of the narrow-mindedness of the stereotypically racist American response. Changez transports himself from one fundamental fantasy to the next in order to provide himself with bearings as the coordinates of his reality shift. The technique of dramatic monologue that Hamid utilizes in his work gives us an initial view of Changez in retrospect as an aspiring Pakistani on scholarship in Princeton University. His brilliant academic tenure leads gradually to an even more brilliant professional opportunity at Underwood Samson, where he is soon earmarked for his performance. The present state of the narrator, however, gives him a profound apparent fundamentalist look as he explains to the muscular American he has just met, "Do not be frightened by my beard: I am a lover of America" (1). It is the complex nature of the transition that we see in Changez that marks him as a truly human character, who has his contradictions and profound moments of doubts.

Changez also finds it ironical that after 9/11, when he chooses to keep a beard, he can spot uneasy glances of impressionable colleagues who have already begun to show signs of ideological alliances. "Žižek further points out, our tolerance and our freedom of choice are revealed in their inconsistency when we cannot tolerate a Muslim woman who chooses to wear the burqa" (Wood 285). The thought of Changez's origin might be embarrassing for him, but it is an unbearable truth easier to live with than the American ideological pillars that he artificially identifies with. Therefore, his option to squirm out of the ideological manipulation of American repercussions is totally sane. He also realizes the grim responsibility of educating the youth of his third-world home country Pakistan as to how America subtly manipulates their policies to keep them dependent, as Žižek elucidates in Violence: "the developed countries 'help' the undeveloped with aid, credits, and so on, and thereby avoid the key issue, namely their complicity in and co-responsibility for the miserable situation of the undeveloped" (22). The global policeman (America) effectively plays its role to secure natural resources with financial potential. Changez wanted to reveal the truth of this systemic violence in order to share with his countrymen his broader acquired vision from the American experience. Erica had already noted at one point in the novel that Changez seemed to come "alive" when he started talking about Pakistan and the family he had left behind (93). America became a greater alien territory in the wake of the tragedy, and Changez became painfully aware of it: "Often I would emerge into the car park to find that one of the tires of my rental car was punctured -- far too often for it to be a mere coincidence" (109). At the same time, Changez's empathetic reaction to Muslims, particularly Pakistanis around the world, made him question his affiliations: "I was uncomfortable with the idea that the place I came from was condemned to atrophy" (110-11). After all, "Focus on the fundamentals" (112) was Underwood Samson's guiding principle, and he started doing just that. Deportations of Muslims and uncalled-for raids on civilian houses left his faith in America shaken. Changez felt that he had emerged thankfully from a state of selfdeception (114) and could now move towards the direction that was meant for him to pursue with dignity. The predominantly racist attitude of many Americans after 9/11 was another Repressive State Apparatus that Changez wanted to unfetter. But it is interesting to note that Changez becomes painfully aware of his existential dilemma in America when his American love Erica, not only fails to reciprocate his love, but dwindles into the abyss of nothingness, leaving Changez with a poignant feeling of unrequited love and indelible loss. As Myers says in his book about the concept of the relationship of men and women which can be observed in the case of Changez's love life, "woman is the limit of the abyss against which man defines himself" (62). Changez's world of idealism, political correctness and false sense of security comes tumbling down in correspondence to Erica's deterioration and ultimate vanishing. America fails, socially and emotionally, in providing a tether for Changez's insecurities. 
Far from looking at America as the universal ideal or godfather of this world, Changez's perception evolves to enable him to draw a contrast between his present American abode and his roots of a former colony, a colony which together with other colonies, are culpable in providing imperial powers with their false sense of superiority. In the façade of the American halo of success, Changez discerns his own position as being one of the instruments for augmenting the phenomenon of some social animals being more 'equal' than others. The standardized tests of America (like SAT) were traps to attract the intellectual cream of other nations, leaving the home countries deprived of brain power, while the migrants became servers of a tentacled capitalist cause. Changez realized gradually that he was just enabling the tentacles to grow more out of bounds. In fact, sometimes the media becomes the exhibitionist cause of perpetuating a false consciousness (Marx referred to ideology this way). Thus the American Dream would be a success Myth reinvented and represented by the Media until the average mind started believing that it's nothing but the truth that he perceives on screen. His interviewer at Underwood Samson rightly upraised him as a typical specimen of the sub-continent, "You're hungry, and that's a good thing in my book" (10). A person, hungry for opportunities and on financial aid, would be more likely to lap up and be swept away by the offers coming his way and less likely to err, as he would not like to be a loser in any case. And in America, you just have a guaranteed place for winners. It is this Lacanian Imaginary domain in America that Changez seems to be questioning, the domain described by Myers as, "the Imaginary designates a restless seeking after self, a process amalgamating more and more instances of replication and resemblance in order to bolster up the fable of its unity" (22). So even after responding to this call of the Imaginary world of American wholeness, Changez does not become fully part of the Symbolic framework of American society, as fragmentations of racism, injustice towards various factions of society and the ethereal nature of the American dream seem to belie its unity. Changez made a journey from Pakistan to America, from imperfection to another imperfection, and eventually he opted for one which he could really call his own imperfection without the parading of the term 'democracy'. Kelsey Wood states in his analysis of Lacan that the "Master-Signifier is an empty signifier which has no signified content" (8). For Changez, the space of the empty signifier is sometimes occupied by God (he drinks alcohol despite being a Muslim and makes love to Erica out of wedlock) and later by America itself (in the wake of the 9/11 attacks). The undeclared imperialism of USA forces Changez towards a reluctant but progressively growing fundamentalism, where his beard flaunts his rebellion rather than his faith (note Changez's belligerent speeches and protests organized towards the end). Both America and Erica had been his beloveds, but both become victims of nostalgia (America trying to revive its lost glory and supremacy after 9/11 and Erica trying to recover her ideal love interest, Chris). Mohsin Hamid, through his monologue, unfolds the decay of Erica's sensibility side by side the great American tragedy, "The destruction of the World Trade Center had, as she had said, churned up old thoughts that had settled in the manner of sediment to the bottom of a pond; now the waters of her mind were murky with what previously had been ignored" (94). The choice of the word "ignored" shows that Erica's reality in the form of Jim's death is very much a part of her constitution in the same way as Changez cannot shake off the dark call of his origins that demand a completion of their own fantasy of lost splendor. Ironically, Changez's struggle with himself later in Manila seems to echo Erica's state, "I had come to suspect that hers were not merely the lapses of the absent-minded; no, she was struggling against a current that pulled her within herself, and her smile contained the fear that she might slip into her own depths" (98). Changez also becomes preoccupied with clutching trances when his inner self threatens to assert itself against his illusion of American perfection, and his trauma leads him towards a change of perspective, yet another anamorphic image. Nevertheless, Changez engages in an 'act' which risks the impossible by breaking off from a coveted standardized American position.

The Twin Towers represent a fantasy of completion for the American Symbolic Order, the crumbling of which leads to a disorientation which makes many question if there is such an entity as a superpower. At this point, one may make a connection to Spielberg's masterpiece Titanic where Rose's (acted by Kate Winslet) fiancé declares the impeccable power of the ship: "Even God couldn't sink this ship". Ironically, in these very words is the Real threat which makes one anxious about the ship's fate; nobody is infinite and invincible (the formula of unraveling is imbibed in the very essence of every existing being/object). In Manila, the Filipino jeepney driver stirs Changez like an alter ego, who is linked to him with a kind of "Third-World Sensibility" (77). It is his very Real origin that would go on pursuing Changez like a shadow and that would overpower him like Kurtz is overpowered by his primordial side in Heart of Darkness. He would be remarkably pleased at the symbolic collapse of the twin towers, but baffled by his spontaneous reaction of enjoyment: "So when I tell you I was pleased at the slaughter of thousands of innocents, I do so with a profound sense of perplexity" (83). 
It is because jouissance is never really divorced from pain and suffering. He knows he will remain an other in a foreign land, and his diasporic identity asserts itself in reaction. At one point in The Reluctant Fundamentalist, Changez talks about his soccer experience at its best, "There was a mental state I used to attain when I was playing soccer: my self would disappear, and I would be free, free of doubts and limits, free to focus on nothing but the game" (14). So his own self becomes a limiting aspect of his life, which is subject to multiple weaknesses as can be seen at various instances in the monologue. At the same time, the contradiction and void in the self is what makes it complete, as perfection only halts progress. Changez is on his journey towards a discovery of this very real void which cannot be denied in his personality. Tellingly, the rift and shift in Changez's personality can be detected one lighthearted day when he is joking with his fellow Princetonians and talking about his dream "one day to be the dictator of an Islamic republic with nuclear capability" (33) indicating his homeland Pakistan, when without being aware of it, he is hinting towards seeds of fundamentalism (rebellious/non-conformist rather than religious) waiting to sprout in his personality and ready to challenge the 'superpower' fundamentalism of America. Changez becomes like a nostalgic subject, constantly trying to recover a sense of identity and completion that evades him, and this parallax is what Žižek regards as the human Real. Ironically, Changez's alienation from American culture comes after spending a considerable period of time, but we cannot say that he becomes reconciled to his own culture. His identity remains viscous... difficult to pin down. But towards the conclusion of Hamid's venture, one thing is a clear; on a microcosmic level, the American representing the West and Changez representing the lost glory of the East, are clearly suspicious of each other, even to a paranoid extent. Joseph Darda comments upon Changez's appearance, "Maintaining a beard is Changez's way of reminding himself of and thereby offsetting the American norms that restrict his capacity to recognize the lives of others" (116). America has accepted Changez into its capitalistic progressive mould, but the mould is too restrictive for the Pakistani's spirit. He refuses to become a modern janissary (the Christians who served the Muslim Ottoman Expeditions against fellow Christians) for the American superpower/empire. He becomes a rather manipulative and sinister character in his encounter with the American, encircling and tightening his psychological threat around the American and his address towards the American is reflective of mind games meant to overwhelm the person at the receiving end who begins to show "the behavior of an animal that has ventured too far from its lair and is now, in unfamiliar surroundings, uncertain whether it is predator or prey!" (35). So Changez refused to be a writer of the American grand narrative and his linguistic prowess went into the seduction of young Pakistani minds as professor. Žižek would probably have a lot of respect for Changez's divergent perspective finally becoming focused, even if in favor of a reluctant fundamentalism, a fundamentalism that would lead to the fundamentals of his inner identity asserting itself against repressive odds. However, Changez never really becomes contented with his position throughout the monologue; he remains a prisoner of first one set of beliefs, then another. His political sermons at the end speak volumes of his slavery to another cause. He has given up completely the enjoyment of being totally free: "The essential life substance is jouissance, of which the subject is usually unaware. Enjoyment is Real; it is the price we pay for being symbolic animals, or speaking beings" (Wood 23). His speech becomes a tool for attracting political followers; however, he is never fully resolved of the conflicts inside him or at peace with himself.

To quote from Myers's work on Žižek, "we all engage in a minimum of idealization, disavowing the brute fact of the Real in favor of another Symbolic world behind it" (50). Like all young men, Changez had dreams and ideals, and he found in America a platform for realizing those dreams. Symbolically, America was a land of opportunities and progress, shimmering incessantly for aspiring third-world inhabitants. Žižek says in "Of Cells and Slaves":

The way I "see myself," the imaginary and symbolic features which constitute my "self-image," or even fundamentally, the fantasy which provides the ultimate co-ordinates of my being is neither in the genes nor imposed by the environment, but the unique way each subject relates to him or herself, "chooses him or herself" in relationship to his or her environs, as well as to (what he or she perceives as) his "nature". (Wright 314)

Changez is not a static character; he evolves with the transition of his circumstances and the way he relates to America undergoes a radical change. This is because the apparently perfect and invincible ideology behind the American statue of Liberty is a wobbly one. As Žižek discusses in his work The Sublime Object of Ideology, we become the active perpetrators of capitalism the way we are schooled, educated and trained but we fail to question this skewing of knowledge. That is why we experience a profound sense of displacement whenever an ideological formula goes wrong. This false sense of wholeness that ideology provides often proves to be its undoing. 
Žižek rightly indicates that we literally perceive judgments: "what we perceive as immediate reality is directly a judgement" (Daly 55). That judgment is not a universal; it is just a point of view to provide a bogus sense of security. In a world where histories are misrepresented and altered, where violence is justified in the name of justice and where economic gains and imperial hubris become fundamentalisms, Changez is likely to feel diasporic unease. The fear of the 'other' is also one such fundamentalism which makes perspective limited: Changez did not want to have that singular vision. America is displaced from the status of being a dream to a nightmare that makes Changez question his reality. Post 9/11, Changez's beard is perceived as an open threat by the stunned American mentality, which previously would have been accepted as Changez's personal/individual choice. The equation of Muslims with terrorists was also experienced first-hand by Changez. However, Changez was lucky enough to experience the antagonism mildly as he had become incorporated into the American corporate fabric. Nevertheless, this privileged concession was seen as a vulnerability and weakness by Changez, as he reflected upon his position akin to servility to a state that would soon be targeting a number of Muslim countries in retaliation and blind anger. So America itself was a perpetrator of stereotypical discrimination, and Changez found it difficult to digest precisely that. The American policy was hollow to begin with, and Changez found himself a slave to a cause without substance. The traumatic class struggle between America and the Third World was very real, and religion became the scapegoat for justification of the American policy after the Towers Collapse. This was enough to unhinge his bearings and he passed several weeks in listless preoccupation. The quest is to find the root of the problem that makes one restless, and Changez would rather channelize the energy of this restlessness in his own country. In this hour of need, Changez was one of those intellectuals who would rather go back and utilize his brainpower in something constructive for his own country. The Protests organized by his students might well be taken as questioning the capitalist/proletariat divide between not only persons, but whole countries, where the more privileged countries keep the poorer ones dependent, not only by attracting their brainpower, but by keeping them dangling nicely through donations that help them to survive (but that do not dare to help them rise above themselves). Religion was dragged into the tug and pull of the power dynamics of the world, and false stereotypes emerged that might as well disturb young men like Changez whose 'cogito' was very much alive. Changez, in a way, is successfully struggling to evade labels by the end of the monologue, and possibly evades being a political prisoner through a waiter's assistance at the end.

Viewing Pakistan as a young country, we can say that it has still not gotten out of its Lacanian 'mirror' stage where the ego is envisioned and brought to birth. Its multiple vicissitudes of history have prevented it from reaching the full potential that it might be capable of, rendering it an infant, a third-world country still struggling for survival and self-respect. Towards the end, Changez is somewhat like a radical visionary who must inculcate consciousness among his students (the architects of the Pakistani future). He realizes that Pakistan, an infant nation still struggling to emerge in the world arena, needs his services more than America (which incidentally made the 9/11 issue an egotistical one to restore its lost pride). Changez tries to confront his self-deception of being a pseudo-American. So from being touchy and ashamed about his origins, he comes to a wavelength with his identity that must restore his own country's lost glory first before it tends to any other cause.

The book has been a receiver of mixed reviews. James Lasdun aptly asks in "The Empire Strikes Back", "By what higher personal virtue does Changez presume to judge? The question opens the book to the charge of a more serious flaw: one expects Changez's opposition to America's conduct to be founded on some morally superior alternative set of values" (See Works Cited). If Changez found America's conduct to be disturbingly intrusive, he fails to provide a justification for his own conduct which appears at best vengeful and ungrateful at the same time. However, we cannot accuse Mohsin Hamid of creating a mouthpiece in the character of Changez as Changez has his weak moments a number of times. In fact, Changez often appears to be an opportunist (asking Erica to imagine that he is Chris so that he can make love to her, plus staying with his firm as long as America is unperturbed). Changez also becomes a victim of the post 9/11 paranoia; the American he meets on the street of Lahore is repeatedly thought of by Changez as trying to take out a pistol. Similarly, through Changez's monologue, we get to know that the American is equally suspicious of bearded Pakistanis and their acquaintances, repeatedly thinking that perhaps the tea he is being offered is poisoned or that someone is stalking him. Changez, America and Erica, in their own individual ways, had to confront their personal traumas, which Lacan considers as the point where the Real interrupts the flawless functioning of the Symbolic Order (Myers 26), namely Changez's practical aspirations, American Dream and corresponding perfect society and Erica's nostalgic view of a perfect love. These are rigid concepts and designators with a very fragile base that cannot stand the pressure of reality. 
In fact, human beings are first prisoners of their own narcissistic yet confused selves before their symbolic world can be blamed. Both America and Erica have emotional baggage that is vented out on victims who are perhaps well-wishers or who are not the trauma originators. In fact, many of the American-targeted victims are just displaced objects of the American wrath resulting from its broken image. Wood nails this reactionary American fantasy in the head, "The ideological fantasy arose of a national enemy, an ethnic or religious other who disrupts "natural" social stability" (58). These religious others had to be punished severely in Uncle Sam's vocabulary of self-preservation. Just like Blacks and Muslims would always be the others in the American community life, Changez would always be the other, inferior lover who cannot be accepted into Erica's world. So America and Erica can never be referred to as homes, no matter what happens. The unjustified deportation of many migrants is testimony for that. Abhimanyu Chandra derisively comments about Changez as a weak, selfish character because "The problem with his politics is clear: he fails to hold his homeland, Pakistan, and himself to the same standards and expectations to which he holds America" (See Works Cited). Changez also seems to forget that America, like Pakistan, is a former colony. Chandra questions the infallibility of the ideals that Changez develops through the progress of the monologue and highlights the pitfalls of Changez's radical turnabout. But we need to remember that Mohsin Hamid deliberately created such a character who was not perfect and who, luckily enough, would be actively engaging the readers in individual responses. Changez was also a character who seemed to be questioning the notion that inspite of being a former colony, America felt no remorse in assuming the role of a super imperial power (strategically speaking) and exploiting the dependence of weaker nations. The capitalist manipulation followed by such powers is what critics like Žižek question, "All Žižek can say at present is that he wishes to reject that which we have-capitalism-in the hope that it opens up the space for something better-a space in which subjects are not paranoid narcissists who have become beleaguered by their own enjoyment and find pleasure only in servility" (Myers 61). This "something better" is what Changez is still in the quest of, and he would prefer to engage in this quest through activities conducted in his own country rather than a blinkered vision of borrowed Americanness. A fantasy of American wholeness is likely to crumble apart, and his fragmented experience is a richer experience that would enable him to embark on his personal voyage of self-discovery. Just like every Prospero needs a Caliban to strengthen his identity, America needs subversive forces like Taliban to reinforce the American success myth that guarantee its hegemonic hold over many generations to come. Wood in his work on Žižek stresses the importance of identifying the common political enemy that threatens the world today: "Who is this common political enemy? Today it is the imposition of the world market which undermines local ethnic traditions, and even undermines the nation-state itself" (157). Capitalism and a quest for an ever-prevalent need for controlling the power monopoly manipulate the world scenario in a furtively destructive way to direct the control of power dynamics into a few selected nations. Wood further discusses about Žižek's stance on the firstworld citizens who recklessly enjoy their privileged positions and normative standards and ignore the trials and tribulations the Third World natives have to face: "Our political cynicism, rationalizations, and lethargy make it easy for our leaders to invade other countries in order to exploit the natural resources there. We are blind to our own participation in the excesses of global capitalism; we remain willfully ignorant of the fact that our "freedom" to consume cheap products is bought at the price of unimaginable suffering in the Third World" (191). Changez is that subject of the Third-World origin who has been jolted to an awareness of his ultimate standing in the world scenario. He decides to step into the shoes of his native sufferers while forfeiting a privileged position of a janissary in the American Empire, thereby making it stronger. He chooses his homeland to pursue what seems a nobler proposition to him. Changez rejects the fallacy of so-called democracy in favor of a retaliatory fundamentalism. Changez shakes off the role of a puppet in a virtual reality performance. He cannot be blind anymore to the root cause of it all as Žižek believes that the deep-rooted cause of visible acts of terrorism is the invisible yet systemic violence of the tug and war of global capitalism (Welcome 49). In the same treatise, Žižek's stance would likely commend Changez's ability to question his real stance: "The true ethical courage involves the ability to thoroughly question one's own position" (75). This is what Changez ventures out to do as he leaves America. He realizes now that he would never be embraced by the narcissistic America unless he was a National just as Erica would never accept his love unless he pretends to be Chris (both of which are fundamental prerequisites). He could not, at one juncture, quite digest the idea of a belligerent American man calling him "Fucking Arab" (134). Changez was morally offended by the fact that in seeking to preserve a professional microuniverse (his firm), "no thought was given to the critical personal and political issues that affect one's emotional present" (165). Changez felt that he was colluding in the infrastructure of a system with which he shared no common cause. 
But on the whole, he did feel himself to be a victim of collateral damage, whether as a janissary being used for imperial purposes or as a beholder of innocent civilians dying in his region indiscriminately along with the terrorist targets. It was as if an exile had reestablished his links with his homeland, his primitivity, his unabandoned Pakistani identity, so much so that towards the end, he feels like a "Kurtz waiting for his Marlow" (208). He has confronted his nightmarish fears of origin and can finally identify himself in new fundamental terms (not terrorist fundamentalist but inquisitive fundamentalist curious about what really defines him). So he forfeits his ignominious position of a dummy to ascertain his genuine leanings in the world. To counter Chandra's objection to characters like Changez, Laila Halaby succinctly defends the creation of such characters and such books, "Some books are acts of courage, maybe because the author tries out an unproven style, addresses an unpopular theme or allows characters to say things that no one wants to hear" (See Works Cited). Furthermore, Erica, the female protagonist of Mohsin Hamid's work, says while discussing her own authorial venture, "It's more a novella than a novel....It leaves space for your thoughts to echo" (58). So the artistic venture must be taken as a contemplative canvas the moment it is completed. It has many stories associated with it and one of those stories must be provided through the reader's speculative response.

Many readers would interpret Mohsin Hamid's portrayal of Changez as extremist, terrorist or fundamentalist by the end of the monologue and be purveyors of criticism but that is what Mohsin Hamid wants; the reader is a character too who will shape Mohsin Hamid's narrative further (Interview to The Guardian: See Works Cited). The reader must be provoked before a healthy judgment is to be reached. And in Mohsin Hamid's work, the judgment is never a simple black or white. It involves grey areas waiting to be explored and questioned. Mohsin Hamid describes the style as "an appropriate permeable form, a dramatic monologue, a half-conversation spoken to "you" that leaves it to the reader to supply its missing context" (Interview to The Guardian). It is an invitation towards which the reader is provoked to respond as a character, so passivity is replaced by positive and interactive reader-response. The book successfully captures the Zeitgeist (Hegelian term) and modern readers would identify with several issues touched upon by the author.

\section{References}

Abrams, M.H, gen. ed. "Dramatic Monologue". A Glossary of Literary Terms, 8th ed. Thomson Wadsworth, 2005, pp. 70-71.

Awan, Muhammad Safeer. "Global Terror and the Rise of Xenophobia/Islamophobia: An Analysis of American Cultural Production since September 11”. Islamic Studies, vol. 49, no. 4, 2010, pp. 521-537.

Butler, Judith, Ernesto Laclau, and Slavoj Žižek, Contingency, Hegemony, Universality: Contemporary Dialogues on the Left. Verso, 2000, p.234.

Chandra, Abhimanyu. "Review: The Reluctant Fundamentalist". The Yale Review of International Studies, Aug. 2012, www.yris.yira.org/bookreviews/514. Accessed 10 June 2018.

Darda, Joseph. "Precarious World: Rethinking Global Fiction in Mohsin Hamid's "The Reluctant Fundamentalist"'. Mosaic: An Interdisciplinary Critical Journal, vol. 47, no. 3, 2014, pp. 107-122.

Halaby, Laila. "Review of The Reluctant Fundamentalist". The Washington Post, 22 Apr. 2007, www.washingtonpost.com/wp dyn/content/article/2007/04/19/AR2007041903000.html?noredirect=on. Accessed 11 June 2018.

Hamid, Mohsin. "On Writing The Reluctant Fundamentalist". 14 May 2011. The Guardian, www.theguardian.com/books/2011/may/14/mohsin-hamid-reluctant-fundamentalist-bookclub.

Accessed 14 June 2018.---. The Reluctant Fundamentalist. Penguin Books, 2007.

Kramatschek, Claudia. "Review of The Reluctant Fundamentalist". Translated by Christina M.

White. Qantara, www.en.qantara.de/content/mohsin-hamid-the-reluctant-fundamentalist. Accessed 12 June 2018. Lasdun, James. "The Empire Strikes Back”. The Guardian, 3 Mar. 2007, www.theguardian.com/books/2007/mar/03/featuresreviews.guardianreview20. Accessed 15 June 2018. Myers, Tony. Slavoj Žižek. Routledge, 2003.

Olsson, Karen. "I Pledge Allegiance". April 22, 2007. New York Times, www.nytimes.com/2007/04/22/books/review/Olsson.t.html. Accessed 16 June 2018.

Sooke, Alastair. "Review of The Reluctant Fundamentalist". The Telegraph. 18 April 2007. 
www.telegraph.co.uk/culture/books/fictionreviews/3664515/Man-Booker-2007-Prize-The-Reluctant-

Fundamentalist.html. Accessed 13 June 2018.

Wood, Kelsey. Žižek: A Reader's Guide. $1^{\text {st }}$ ed., John Wiley \& Sons, Inc., 2012.

Žižek, Slavoj. Did Somebody Say Totalitarianism? Five Interventions in the (Mis)use of a Notion. Verso, 2002.

---. For They Know Not What They Do. Verso, 2002.

---. How to Read Lacan. Norton, 2007.

---. Iraq: The Borrowed Kettle. Verso, 2005.

---. Looking Awry: An Introduction to Jacques Lacan through Popular Culture. MIT Press,

1992.

---. "Of Cells and Selves". The Žižek Reader, edited by Elizabeth Wright and Edmund Wright, Oxford, 2009, p. 314.

---. On Belief. Routledge, 2004.

---. "Religion between Knowledge and Jouissance". Lacan.com. www.lacan.com/zizsmokeonthewater.html. Accessed 18 June 2018.

---. The Plague of Fantasies. Verso, 1997.

---The Puppet and the Dwarf: The Perverse Core of Christianity. MIT Press, 2003.

---Welcome to the Desert of the Real: Five Essays on September 11 and Related Dates. Verso, 2002. 